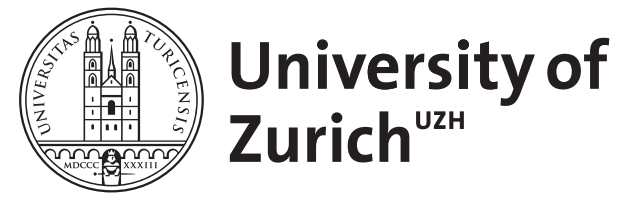

\title{
Eder (Place)
}

Arnet, Samuel

DOI: https://doi.org/10.1515/ebr.ederplace

Posted at the Zurich Open Repository and Archive, University of Zurich

ZORA URL: https://doi.org/10.5167/uzh-87965

Book Section

Published Version

Originally published at:

Arnet, Samuel (2013). Eder (Place). In: Klauck, Hans-Josef; Leppin, Volker; McGinn, Bernard; Seow, Choon-Leong; Spieckermann, Hermann; Walfish, Barry Dov; Ziolkowski, Eric J. Encyclopedia of the Bible and Its Reception : Volume 7: Dress - Essene Gate. Berlin/New York: De Gruyter, 391-392.

DOI: https://doi.org/10.1515/ebr.ederplace 
of Eden (dir. E. Kazan, 1955), Paradise Lost (dir. H. Freed, 1999), Adam \& Eve (dir. I. K. Musallam, 2002), and Eden (dir. D. Recks, 2008).

Bibliography: - Dixon, W. W., Visions of Paradise (New Brunswick, N.J. 2006). - Kozlovic, A. K., "Serpentine Evil and the Garden of Eden: On DeMille's Samson and Delilah (1949)," Bright Lights Film Journal 60 (May 2008; www.brightlightsfilm.com; accessed August 27, 2013). - Linafelt, T., "The Human Condition in Genesis 2-3 and in Blade Runner," in Teaching the Bible (ed. M. Roncace/P. Gray; Atlanta, Ga. 2005) 73-75. - Sanders, T., Approaching Eden (Lanham, Md. 2009). - Sterritt, D., "Days of Heaven and Waco: Terrence Malick's The Tree of Life," Film Quarterly 65/ 1 (2011) 52-57.

Anton Karl Kozlovic

See also $\rightarrow$ Adam (Person); $\rightarrow$ Adam and Eve, Story of; $\rightarrow$ Eve; $\rightarrow$ Garden; $\rightarrow$ Lilith; $\rightarrow$ Paradise

\section{Eder (Person)}

\section{Son of Mushi}

One of Mushi's three sons, Eder (MT ' $\bar{E} d e r)$ is mentioned in two lists of Levites who served under David (1 Chr 23:23; $24: 30$ ). Mushi was son of Merari son of Levi (1Chr 23:21). Rather than deriving from an early monarchic period, the lists correspond to hierarchies and influences of Levite families during the Second Temple period. Eder may be a short form of Adriel ('Adrî̀el), 'El is my help' (Aram.).

\section{Son of Beriah}

Eder (MT 'Eder), Son of Beriah, a descendant of Benjamin, is mentioned in $1 \mathrm{Chr} 8: 15$. The verse is part of a list of heads of families who lived in Jerusalem. Although the list purports to be from an early period, it is more probably related to Jerusalemite families during the Second Temple Period. As with many other names, the Greek versions bear witness to several variants of the name $(\Omega \delta \varepsilon \varrho, E \delta \varepsilon \varrho, A \delta \alpha \varrho)$. Juha Pakkala

\section{Eder (Place)}

According to Josh 15:21, Eder is a settlement in Judah located "in the extreme south, towards the boundary of Edom.” While MT has 'E Eder, the LXX

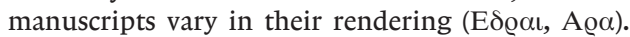
Since in early Hebew script the consonants $d$ and $r$ look very similar, it may be that the name should read Arad rather than Eder (see Josh 12:14; 1 Chr $8: 15$, though in a different context, lists both Arad and Eder). The place names in Josh 15:20-63 should demonstrate "how vast and rich Judah once was” (Knauf: 145).

Bibliography: - Knauf, E. A., Josua (ZBK Altes Testament; Zürich 2008). - Svensson, J., Towns and Toponyms in the Old
Testament (ConBOT 38; Stockholm 1994). - - Zorn, J. R., “Eder,” ABD 2 (New York 1992) 284.

Samuel Arnet

\section{Eder, Tower of}

The Tower of Eder (MT Migdal-'éder, lit. "tower of the flock") is situated near the place beyond which Jacob/Israel pitched his tent after Rachel's death when on his way to Hebron (Gen $35: 21,27)$. It was identified by Jerome with the Shepherds' Field (Epist. 108.10), where God's angel announced Jesus' birth to the shepherds (Luke 2:8-14). The place, located about $1 \mathrm{~km}$ east of Bethlehem within the Arab village of Beit Sahur, has been associated with messianic expectations (cf. Mic 4:8); Targum Pseudo-Jonathan on Gen 35:21 states that Migdal' $\bar{e} d e r$ is the place from which the Messiah will reveal himself at the end of days.

Bibliography: - Liid, D. C., "Eder, Tower of," ABD 2 (New York 1992) $284 . \quad$ - Tsaferis, V., "Shepherds' Field," in The New Encyclopedia of Archaeological Excavations in the Holy Land (ed. E. Stern; New York 1993) 1362-363.

Samuel Arnet

\section{Edersheim, Alfred}

Alfred Edersheim (1825 - 1889) was the author of numerous popular books on the OT and NT as well as on the Jewish people. Although he was born in Vienna of Jewish parents and received his initial education in a school attached to a synagogue, as a young man he converted to Christianity. He eventually became a minister of the Free Church of Scotland and later took orders in the Anglican Communion. His most famous book, The Life and Times of Jesus the Messiah (2 vols., 1883), emphasizes the Jewish background and context of the canonical gospels. Uncritical by modern standards, both in its historical judgments and its use of rabbinic materials, it nonetheless displays a remarkable knowledge of Jewish sources and their importance for the study of Jesus and early Christianity. Although the book had very little impact upon academic circles, it is still in print and remains popular in some English-speaking Protestant circles.

Bibliography: - Mishkin, D., The Wisdom of Alfred Edersheim (Eugene, Oreg. 2008).

Dale C. Allison, Jr.

\section{Edessa}

I. Christianity
II. Islam

\section{Christianity}

Edessa had been the incontestable cultural capital of the Aramaic speaking Christendom on Roman territory and was to maintain its pivotal role at least 